\title{
Securitizing Higher Educational Loans for Cheaper Cost of Financing and Higher Return on Investment in Malaysia
}

\author{
Ismail.S \& Ali,R
}

Faculty of Business and Management, Universiti Teknologi MARA, Melaka 75300, Malaysia

Bakri,M.H

Faculty of Technology Management and Technopreneurship, Universiti Teknikal Malaysia, Melaka 76100, Malaysia

\section{Azman M.N}

Kulliyah of Economy,Universiti Islam Antarabangsa, Kuala Lumpur 50728, Malaysia

\begin{abstract}
Research has shown that the default rate is higher for those countries that implement the mortgage-type loans. Many researchers have tried to address this issue, usually by analyzing the types of repayment collections such as income contingent loans that can minimize the default rate. However, Malaysia implements mortgage type funding to the student in order for them to continue studies and the default rate is high due to default on repayment. Therefore, this study particularly focuses on how to minimize default by introducing new framework, which has not yet been implemented as a securitization process in Malaysia. This work suggests a structure for Islamic student loan-backed securitization, and studies the potential of the Islamic student loan-backed securitization in resolving the educational loans problem. The main purpose of this research is to investigate the possibility to implement Islamic Student Loan-Backed Securitization that meets shariah-compliance in Malaysia. It is expected that the Islamic student loan-backed securitization that based on the Human Capital Theory become a cheaper cost of financing and higher return on investment in Malaysia. This work proposed a structure of highly graded and marketable sukuk that complies with global shariah principles that will help the Malaysian government to produce high income nation.
\end{abstract}

KEYWORD: Islamic student loan-backed securitization; Student Financing; Higher Educational loans; Default; Investment

\section{INTRODUCTION}

In October 2011, the Ministry of Education launched a comprehensive review of the education system in Malaysia in order to develop a new National Education Blueprint. This decision was made in the context of rising international education standards, the Government's aspiration of better preparing Malaysia's children for the needs of the 21st century, and increased public and parental expectations of education policy. The result is a preliminary Blueprint that evaluates the performance of Malaysia's education system against historical starting points and international benchmarks. The Blueprint also offers a vision of the education system and students that Malaysia both needs and deserves, and suggests 11 strategic and operational shifts that would be required to achieve that vision. The outcome of the blueprint will produce more student could access to the primary and secondary school that will make more applicant to further study to higher education. Government need to produce more places in higher institution as well financial assistance.

\section{PROBLEM STATEMENT}

Government has constrained with the budget for financial assistance because of the low and nonrepayment from previous student loan. As of Jun 2014, about 50,000 students may be deprived of their National Higher Education Fund Corporation (NHEFC) loans when they enroll for varsity courses between July and December this year (Berita Harian, 2014).This was because 183,000 people had defaulted on their PTPTN loans, involving a loss of funds involving RM1.3bil."Their failure to pay is serious as they represent $19 \%$ of the total number of PTPTN borrowers so the fund is losing RM1.3bil in future loans," (Malay daily, 2014). Finance Ministry had granted NHEFC a RM4bil allocation for this year, the amount could only cover $75 \%$ of the new and existing borrowers. About $25 \%$ would not get the loans. NHEFC has approved loans for some 1.98 million students amounting to RM 44.18 billion, with the actual dispersed stood at RM30.44 billion, (The Star, 2012, p. 3). While the total sum owed to NHEFC is RM 6.83 billion from 1.09 million borrowers, the corporation has so far only managed to collect RM 3.31 billion. Further statistics by the 
Corporation indicated that although many NHEFC borrowers are showing their interest to pay, the actual sum collected still remains low.

This research thus attempts to proposed Islamic student loan-backed securitization as an alternative financing in the Malaysian higher education (HE), in order to relieve the pressure currently imposed on the government budget (Ismail and Serguieva, 2009). The objectives are to offer student loan with interest free educational funding; to subsidize monthly installment and reduce repayment period up to 5-7 years as well as to cover loan from cumulative outstanding at RM32 billion as at 2011 to fully settle by 2037. Student loan securities have been implemented in other countries; however, it is a new concept for Malaysian HE as Islamic student loanbacked securitization is new and become the first in the world (Ismail \& Serguieva, 2009). The following section considers Human Capital Theory followed by why islamic finance and islamic securitization. Lastly, the proposed framework of Islamic student loan-backed securitization has been presented followed by a conclusion..

\section{HUMAN CAPITAL THEORY}

Human capital theory posits that individuals treat the commodity of higher education as an investment. Human capital theory implicitly and explicitly is the notion that formal higher education renders individuals become more productive. As a result the outcomes will recognized by employers who consequently reward qualified personnel according to their relatively higher marginal product.

The literature abounds with studies that report a significant association between educational attainment and earnings. These observations give weight to the human capital assumption that individuals pursue higher education with primarily economic intent. In fact, only the perceptions, expectations and beliefs of individuals can give meaning to their decisions. Perhaps this explains why relatively few studies have ventured into the realm of individuals' earnings expectations.

Human capital theorists generally offer details skepticism of expected earnings data. In spite of this, the human capital expect that private rate of return is a determinant of higher education choice. This is based on the assumption that individuals are able to anticipate their future income accurately.It has been noted, though, that little evidence exists in support of the belief that those educational investments are able to predict their future income accurately (Blaug 1976, Smith and Powell 1990). This suggests that studies claiming support for human capital theory as a model of educational choice often do so gratuitously on the basis of untested assumptions of the behaviour of economic agents.

\section{WHY ISLAMIC FINANCE AND ISLAMIC SECURITIZATION}

Nowadays, the credit crisis has eroded market confidence, particularly in conventional finance as investors have been flocking to Islamic finance. The Islamic finance industry has grown precipitously in recent years. There are currently more than U.S. 1.3 trillion worth of deposits and investments lodged in Islamic banks, mutual funds, insurance schemes (known as takaful), and Islamic branches of conventional banks. The current growth has been fueled not only by surging demand for shari'ahcompliant products from financiers in the Middle East and other Muslim countries, but also by investors around the world seeking 2009 Islamic investment as a means of diversification, thus rendering the expansion of Islamic finance a global phenomenon (Hesse, 2008).

The current financial crisis invites a distinction of conventional and Islamic finance principles in the context of securitization and a comparison of their capacity to sustain efficient capital allocation and financial stability. Islamic finance is driven by the general precept of extending religious doctrine in the shari'ah to financial agreements and transactions. Shari'ah law bans the sale and purchase of debt contracts, profit-taking without real economic purpose, and activities that are not considered halal (i.e., shari'ah-compliant). The central tenet of this form of finance is the prohibition of riba, whose literal meaning, "an excess," is interpreted as any unjustifiable increase of capital in the form of interest (i.e., usury) whether through loans or sales." Islamic finance is distinct from conventional finance as it substitutes a temporary use of assets by the borrower or a permanent transfer of funds as a source of indebtedness.

Whereas money has become a store of value in conventional finance, the asset-based organization of Islamic finance implies that money is not considered a commodity but a measure of value through which there can be an exchange and payment of goods and services. However, adequate compensation for the sale or temporary use of an asset is encouraged.

Besides the prohibition of interest-based terms of income and unethical activities, Islamic finance is beholden by the objective of maintaining a mutually beneficial balance between borrowers and lenders with a view to serving the public interest (maslaha). Since Islamic law does not recognize the concept of time value of money as in conventional finance, contractual relationships between financiers and borrowers are not governed by capital-based investment gains but shared business risk (and returns) from entrepreneurial investment in lawful activities. The financier receives returns from the direct participation in asset performance in the form of state-contingent payments according to an agreed schedule and amount. Since the religious overlay in 
Islamic finance denies creditors (debtors) the benefit of unilateral gain, shari'ah-compliant finance contracts limit asset price appreciation to the contractually agreed repayment amount.

Although the rapid expansion of Islamic finance is taking place across the whole spectrum of financial activities, perhaps the most striking element has been the fast growth of sukuk, the most popular form of securitized credit finance within Islamic finance. Sukuk encompass a broad range of shari'ah-compliant financial instruments, and can be best described as participation certificates that grant investors return based on profitable investment resulting from actual asset ownership. Since asset backing, entrepreneurial investment, and specific credit participation in identified business risk are fundamental to any Islamic transaction, securitization represents a straightforward capital market-based form of Islamic finance.

Sukuk commoditize the proceeds from asset transfers between providers and users of funds raised from different shari'ah-compliant finance contracts, such as lending transactions or trust based investment in existing or future assets. While sukuk are structured in a similar way to conventional assetbacked securities (ABS) or covered bonds, they can have significantly different underlying structures and provisions. Most importantly, sukuk - like Islamic financial instruments in general--need to comply with shari'ah, which prohibits the receipt and payment of interest and stipulates that income must be derived from an underlying real business risk rather than as a guaranteed return from interest. Thus, sukuk transform the (intended) capital gains generated from actual transactions, such as profitsharing, leasing, or cost-plus sales, into marketable securities without explicit investment protection or principal guarantees.'

\section{PROPOSED FRAMEWORK OF ISLAMIC SECURITIZATION (I-SLBS) IN MALAYSIA}

Higher education in Malaysia comprises of two main categories: government and private. Public higher education institutions are funded by the government, and are similarly governed as self-managed institutions, whilst private higher education institutions include private colleges, private university colleges, open universities, virtual/euniversities and branch campuses of international universities, all of which are also governed as selfmanaged institutions (Ismail et al., 2011). Under the government is the Ministry of Higher Education (MoHE), which was established in 2004 with the purpose of providing strategic direction to the development universities, community colleges and polytechnics. Markedly, both public and private higher education Institutions offer certificates, diplomas, first degrees and postgraduate degrees, whilst polytechnics and community colleges only offer certificate and diploma (Ismail et al., 2011).

This researchis strongly motivated to propose the framework for Islamic Student Loan-backed Securitization (i-SLBS) (Ismail, Bakri, Ali and Mohd Noor, 2014). The new i-SLBS system contemplates the participation of key agents throughout the process: students, higher education institutions (HEI), government, capital market, financial system and the Managing Commission for the whole system. The framework consists of various agents such as follows:

Table 1: Agents of Islamic Student Loan-Backed Securitization

\begin{tabular}{|c|c|}
\hline Agents & Functions \\
\hline Students & $\begin{array}{l}\text { Students will apply to the system through the internet, and they have to provide a proof of their socioeconomic status. } \\
\text { Once they obtained approval, they must go to the bank to sign the legal documentation. After graduated, the salary of } \\
\text { graduates will be deducted } 6 \text { month after the graduates start working. }\end{array}$ \\
\hline $\begin{array}{l}\text { Federal Government / } \\
\text { Ministry of Higher } \\
\text { Education (Mohe) }\end{array}$ & $\begin{array}{l}\text { The federal government that will represent by mohe provides guarantees during the study period. They will select } \\
\text { students who they will support by means of those guarantees and they submit them to the originator. In the annual } \\
\text { budget law, the government determines the amount of resources available for guarantees and the amount of cash } \\
\text { resources available to repurchase loans from the nhefc. The government will assume the cost of the unemployment } \\
\text { contingency and therefore contributes to financing the nhefc for the first } 3 \text { years. }\end{array}$ \\
\hline Originator & $\begin{array}{l}\text { The nhefc centralizes all applications in a single system and orders them from poorest to richest. Nhefc will setup } \\
\text { special purpose vehicle that determines the maximum number of students that can receive the benefit based on the } \\
\text { resources assigned in the fiscal budget law. It organizes the bank tender process. It acquires the loans that the nhefc } \\
\text { are not willing to maintain in their portfolio (those loans continue to be administer by the nhefc that originated them). } \\
\text { It securitizes the loan portfolio acquired from the nhefc and receives and maintains custody of mohe loan guarantees. }\end{array}$ \\
\hline Trustee & $\begin{array}{l}\text { The trustee's primary duty is to protect the interests of the investors who purchase the securities issued pursuant to the } \\
\text { securitization and administer the duties of the spv under the requisite agreements. the natures of the trustee's duties } \\
\text { are specifically set forth in the trust agreement, and frequently require more intensive involvement by the trustee }\end{array}$ \\
\hline $\begin{array}{l}\text { Merchant bank / } \\
\text { financial system }\end{array}$ & $\begin{array}{l}\text { Merchant banks will receive the tender and prepare documents; as well as to evaluate and presenting the offers to } \\
\text { students. They will grant loans to students with direct disbursements and select the loans to be sold to the nhefc. They } \\
\text { also manage the loans in the adjudicated portfolio (including the loans they sell back to the nhefc). }\end{array}$ \\
\hline $\begin{array}{l}\text { Investors / capitals } \\
\text { market }\end{array}$ & $\begin{array}{l}\text { Long-term investors such as pension funds, takaful companies, and mutual funds acquire the securitized portfolios, } \\
\text { both those owned by the national higher education fund and the banks that decide to securitize them. }\end{array}$ \\
\hline $\begin{array}{l}\text { Takaful (islamic } \\
\text { insurance) }\end{array}$ & Takaful (islamic insurance) will cover the student loan if anything happen to the borrower (student). \\
\hline Collection agency & $\begin{array}{l}\text { h many collection agencies to improve collection from student such as the financial institutions, } \\
\text { which is linked to the student database. }\end{array}$ \\
\hline
\end{tabular}


For long term goals, we propose to issue RM50 billion i-SLBS in 5 series in which RM10 billion for initial stage and balance RM40 billion will be issuing after 2 years from first securitization and RM10 billion for every stage (2 years) of securitization with $10 \%$ subsidies for students every year. The five serial issues of sukuk bond RM50 billion in next full 24 years are expected to provide self-funding to NHEFC with interest-free to produce 4.6 million graduates.. With this financing, it is expected to be self-funding by year 2021 ( 7 years after 5 issuances) and fully settle by year 2037 to sukuk-holders as well as the NHEFC outstanding loans amounting RM25.7 billion. Each of these serial issues with world-wide shari'ah endorsement is targeted to capture Gulf-Arab investors which they are looking for reasonable annual return (3.5-4.5\%) from shari'ah-based investments. As shown in Table 3 , Sukuk will be issued in 5 series until year 2022 and maturity period is in year 2037. As a result NHEFC will be no longer depending on government to fund higher education loans.

Table 2: Cash flow for Islamic Student Loan -Backed

Securitization

\begin{tabular}{|c|c|c|c|}
\hline $\begin{array}{c}\text { Sukuk } \\
\text { Wakalah }\end{array}$ & $\begin{array}{c}\text { Issue } \\
\text { Amount (RM } \\
\text { million) }\end{array}$ & $\begin{array}{c}\text { Average } \\
\text { Expected Profit } \\
\text { Rate (\%) }\end{array}$ & $\begin{array}{c}\text { Issue/Maturity } \\
\text { year for each } \\
\text { serie }\end{array}$ \\
\hline $\begin{array}{c}\text { iLMU- } \\
\text { iSFABS }\end{array}$ & $\begin{array}{c}50000 \\
(2014-2037)\end{array}$ & - & - \\
\hline Serie 1 & 10,000 & 3.50 & $2014 / 2035$ \\
\hline Serie 2 & 10,000 & 3.75 & $2016 / 2037$ \\
\hline Serie 3 & 10,000 & 4.00 & $2018 / 2036$ \\
\hline Serie 4 & 10,000 & 4.25 & $2020 / 2038$ \\
\hline Serie 5 & 10,000 & 4.50 & $2022 / 2037$ \\
\hline
\end{tabular}

\section{CONCLUSION}

As Islamic finance conquer the markets. and companies turn to capital market-based sources of finance, sukuk will become essential to the competitiveness of corporations and banks alike (Ali, Ismail, Bakri, 2013). Since conventional securitization is virtually absent in Islamic countries, considerable demand for shari'ah-compliant investment assets, such as sukuk, provides an untapped market for structured finance as a means to advance capital market development. Islamic securitization also complements the battered ABS market as an alternative and more diversified funding option that broadens the pricing spectrum and asset supply. With more than USD 1.3 trillion of credit demand projected to be unmet as the conventional securitization market remains dysfunctional, the current market situation provides a window of opportunity for sukuk.

Islamic finance has got a wide attention as an alternative form of global financing and investment, particularly asset-backed securities. It was proven by the successful launchings of Malaysian Sukuk ABS in 2005. The launchings for global Shariah acceptance has become a strong testimony for big Malaysian companies, therefore continue to issue it as a creative and cheaper debt financing in future. With this framework, it is expected to help government to focus the annual budget to other social facilities such as hospital, school as well as toupgrade transportation system. Since Islamic securitization is part of Islamic bonds in Malaysia, this research is strongly motivated to propose the framework for Islamic Student Loan-backed Securitization in Malaysia, for both markets.

\section{ACKNOWLEDGEMENT}

This research has been presented in a conference and was supported and funded by Ministry of Higher Education and Universiti Teknologi MARA

\section{REFERENCES}

[1] Ali. R; Ismail, S., Bakri M.H. (2013), A Comparative Analysis of Conventional and Shariah for Residential Mortgage-Backed Securities, Procedia Economics and Finance, Science direct (ISSN: 2212-5671)

[2] Blaug, M. (1976) The Empirical Status of Human Capital Theory: A Slightly Jaundiced Survey. Journal of Economic Literature, 14(3), p. 827-855. Cosser,

[3] Hesse, Heiko, Andreas A. jobsc, and Juan Solé. "Trends and Challenges in Islamic Finance." World Economics, Vol. 9, No. 2 (2008a), pp. 175-193.

[4] Ismail, S., Bakri M.H.; Ali. R; Azman Mohd Noor (2014), 'Developing a Framework of Islamic Student LoanBacked Securitization', Procedia - Social and Behavioural Science (Elsevier); PII:S1877042814028730; DOI: 10.1016/j.sbspro.2014.03.691

[5] Ismail, S., Bakri M.H., Ali. R (2014), An Empirical Analysis of Primary Market Spread in Securitizing Government Staff Housing Loans and Personal Loans in Malaysia; Australian Journal of Basic and Applied Sciences; Publisher: American-Eurasian Network for Scientific Information; Vol. 8 (5), pp. 135 - 143.

[6] Ismail, S. and Serguieva, A. (2009). Investigating possible benefits of student loan-backed securitization in the context of the Malaysian Higher Education, Research in Higher Education Journal, Cabell Publishing, USA, Inc. Vol. 5, pp. 1-9.

[7] Ismail, S., Serguieva, A., and Singh, S. (2011). Integrative model of students' attitude to educational loan repayment: A structural modelling approach, Journal of International Education in Business, 4, 2, 125 - 140

[8] Khan, A. (2012). Brighter days ahead for bright student on PTPTN loan, Available from: The Star, 25 May 2012 p3

[9] Smith, H.L. and Powell, B. (1990) Great Expectations: Variations in Income Expectations Among College Seniors. Sociology of Education, 63 (3), p. 194-207 